\title{
PRELIMINARY IMMUNOHISTOCHEMISTRY STUDY ASCERTAINED THE EXPRESSION OF FMRFAMIDE-RELATED PEPTIDES IN THE INTESTINE AND DORSAL ROOT GANGLIA IN MICE
}

\author{
NADA ABDELLAH ABDELSAMEA ABDELLAH ${ }^{1}$; MADEHA AHMED HASHIM $^{2}$ \\ AND MOHAMED-NABIL MUSTAFA ${ }^{3}$ \\ ${ }^{1}$ Department of Histology, Faculty of Veterinary Medicine, Sohag University, Sohag, Egypt. \\ Lecturer of Histology. \\ ${ }^{2}$ Department of Histology, Faculty of Veterinary Medicine, Sohag University, Sohag, Egypt. Lecturer of \\ Histology, Email address:vet_madeha@yahoo.com \\ ${ }^{3}$ Department of Anatomy, Embryology, and Histology, Faculty of Veterinary Medicine, Assiut University, \\ Assiut, Egypt, 71526. Professor of Histology
}

Received: 26 July 2020; Accepted: 31 August 2020

\begin{abstract}
FMRFamide-related peptides are widely disseminated in the mammalian central nervous system. They are involved in abroad pattern biological roles like pain modulation, cardiovascular, and neuroendocrine functions. Although, they have a wide range of functions their source and distribution in different mammalian organs are still not well-known. Numinous studies concerned with FMRFamide-related peptides distribution and biological role in insects and nematodes while the data in mammals are scarce. In the present study using immunohistochemistry, we detected FMRFamide-related peptides in the ileum, colon, and dorsal root ganglia of adult mice.
\end{abstract}

Keywords: Immunohistochemistry, Anti- FMRFamide, Mice, Ileum, Colon

\section{INTRODUCTION}

FMRFamide-related peptides are a class of amidated peptides including, Neuropeptides FF (NPFF), AF (NPAF), and SF (NPSF) (Price and Greenberg 1977, Yang et al., 1985, Yang and Martin 1995 and Panula et al., 1996).

Corresponding author: Nada Abdellah Abdelsamea E-mail address: vet_nada@yahoo.com

Present address: Department of histology, Faculty of veterinary medicine, Sohag University, Sohag, Egypt. Lecturer of Histology
They are expressed and widely distributed throughout the mammalian central nervous system and implicated in a wide range of functions (Panula et al., 1996). Although an anti-opiate effect (Tang et al., 1984 and Malin et al., 1990) and related pain modulation (Yang et al., 1985 and Gouardères et al., 1993) is the most prominent effects of FMRFamide-related peptides, they are also implicated in cardiovascular regulation (Panula et al., 1996) and neuroendocrine functions (Majane and Yang 1990, 
Majane et al., 1993). Interestingly, the precursor protein NPFF gene (ProNPFF), which encodes for NPFF has been cloned and shown to encode not only NPFF, but also NPAF and NPSF in human, murine, bovine, and rat tissues (Vilim et al., 1999). Even though the biological roles of NPFF, NPAF, and related FMRFamides are well identified, their source and distribution in mammals are not well-defined. They represent the main identified family of neuropeptides in invertebrates (Peymen et al., 2014). In insects, FMRFamide-related peptides have been isolated and shown to be distributed extensively throughout the nervous system, salivary glands, accessory glands, and muscle (Orchard et al., 1997). In nematodes, they considered the chief regulators of energy balance, feeding behavior, reproduction, and sensory modulation (Peymen et al., 2014).

\section{MATERIALS AND METHODS}

\section{Animals}

Ten adult male mice BL/6 (wild black mice) were sacrificed for sample collection. Animal housing and handling procedures were conducted in accordance with the European Directive 86/609/EEC.

\section{Tissue processing for immunohistochemistry}

Male BL/6 mice were sacrificed using cervical dislocation and then dissected. Tissues of interest were fixed in $4 \%$ paraformaldehyde solution for 2 hrs. For paraffin sections, after fixation, the tissues were placed in a cassette at the correct orientation. Next, the cassettes were placed in a Histokinette (24 hours-programm) to dehydrate the tissues in ascending series of ethanol solutions, subsequently to be cleared in methyl-benzoate and xylene solutions, and finally infiltrated with melted paraffin in order to become embedded in paraffin blocks. Next, 5 - $\mu$ m-thick paraffin sections were cut using a LEICA RM 2245 microtome.

\section{Immunohistochemistry for paraffin sections}

The paraffin sections were deparaffinized using xylene then rehydrated by gradient ethanol dilutions (100\%-90\%-70\%) and finally rinsed in distilled water. Next, microwave antigen retrieval was performed by heating the sections in $0.1 \mathrm{M}$ sodium citrate/ 0.1 $M$ citrate buffer $(\mathrm{pH} 6.0)$ for $5 \times 3$ min each; subsequently, the slides were left to cool down for $45 \mathrm{~min}$. Blocking of endogenous peroxidase was carried out with $0.3 \%$ hydrogen peroxide $\left(\mathrm{H}_{2} \mathrm{O}_{2}\right)$ solution for $20 \mathrm{~min}$. To block unspecific binding, incubation with (1:5) normal horse serum in PBS with $1 \%$ bovine serum albumin (BSA) was performed. Subsequently, sections were incubated with primary antiFMRFamide (1:500) (MerckMillipore, AB15348) diluted in 0.1 M PBS (phosphate buffer solution) with $1 \%$ BSA overnight at $4^{\circ} \mathrm{C}$. Sections then were incubated with secondary biotinylated donkey antirabbit (1:200) in PBS with 1\% BSA for $2 \mathrm{hrs}$, followed by 3 washes with PBS and incubation with Extravidin peroxidase (1:200) (Sigma) in PBS with $1 \%$ BSA for $30 \mathrm{~min}$. After a washing step, DAB solution (Dako 
K3468) was added until color immunohistochemically. Negative developed and then the reaction was controls in which the primary stopped by washing the section with antibody was omitted or staining PBS. Sections were then washed was done with IgG control did not with tap water and distilled water, yield any immunoreactivity. for $5 \mathrm{~min}$ each, followed by Staining of paraffin-embedded counterstaining with haematoxyline. ileum, colon, and dorsal root ganglia All incubations were performed at (DRG) sections revealed the RT (Room temperature), except for presence of FMRF-amides (Fig.1). those with primary antibody which In DRG FMRF-amide peptides were took place at $4^{\circ} \mathrm{C}$.

\section{RESULTS}

We evaluated the presence of RFamides in DRG (dorsal root ganglia) and in the ileal and colonic wall expressed within the nerve cells and nerve fibers (Fig.1A). In the ileum and colon, FMRF-amide immunoreactivity was detected in enteroendocrine cells and in intramuscular nerve fibers (Fig.1 CF). 

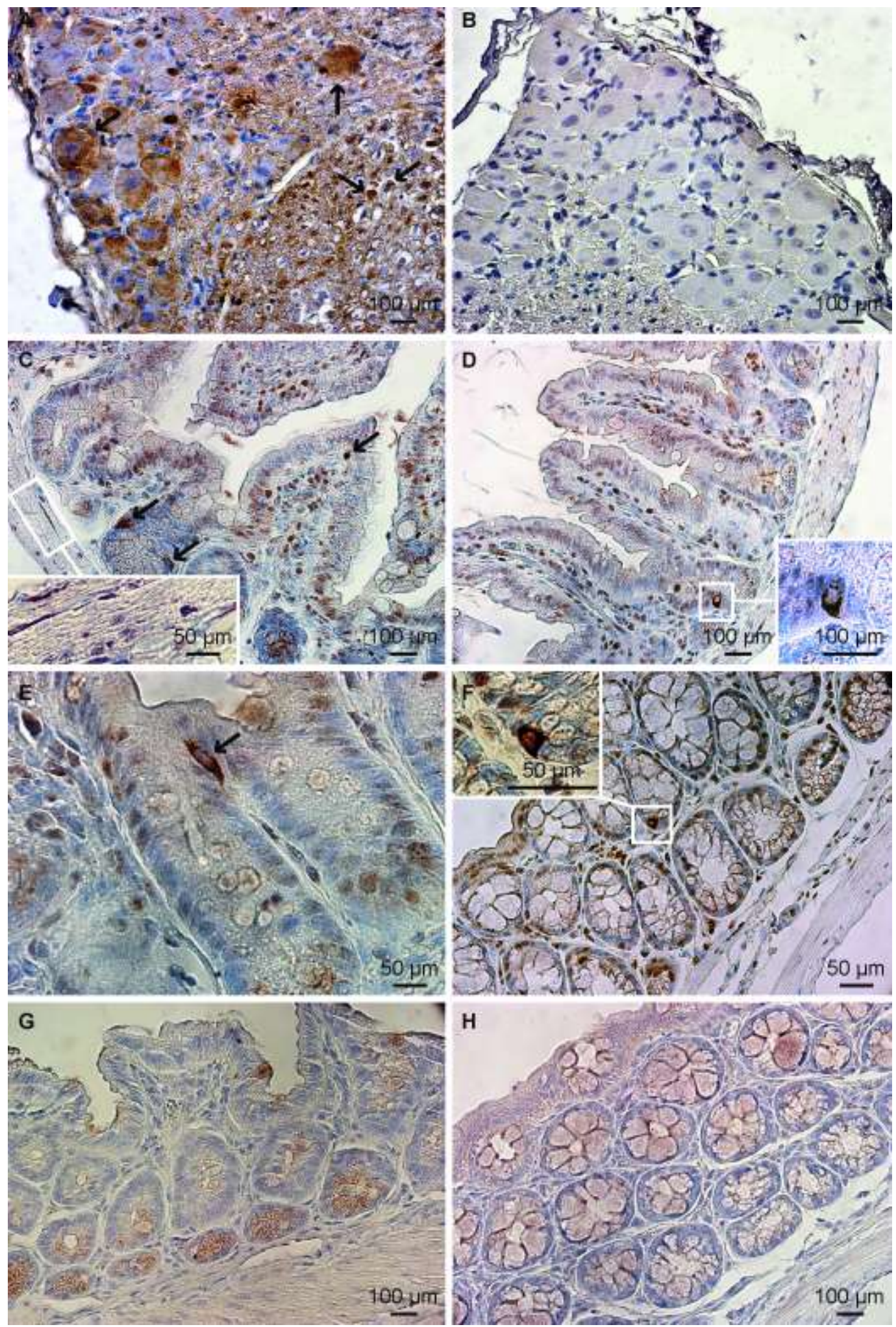

Fig. 1: Paraffin embedded sections, immunohistochemically stained for FMRFamide. (A) FMRFamides were expressed in nerve cells and nerve fibers in DRG (Arrows). (B) Omission of primary antibody led to elimination of immunostaining in DRG. (C) FMRFamides were detected in nerve fibers (square) and in enteroendocrine cells (arrows) in the ileum. (D-E) Enteroendocrine cells showed immunoreactive granules (square, arrow). (F) Enteroendocrine cells were also immunoreactive in the colon (square). (G-H) Staining with IgG control revealed no immunoreactivity in ileum or colon. 


\section{DISCUSSION}

We used the anti-FMRFamide antibody to detect the potential sources of NPAF and NPFF in situ, which revealed the presence of FMRFamide peptides in the enteroendocrine cells and nerve fibers located in the enteric plexuses of the ileum and colon. We had proposed the cells were enteroendocrine cells according to their location and the solitary distribution. Although nothing is known before about the expression and function of RF-amides in the mammalian GI tract it is known that the FMRFamide is the most abundant neuropeptide in endocrine cells of insect alimentary tract (Oetken et al., 2004 and Haselton et al., 2008). Also, we detected the sources of NPAF and NPFF in dorsal root ganglia. Although, early studies proposed that there may be an NPFF-Iike peptide in the sympathetic ganglia and adrenal medulla and not detected NPFF in the spinal or sympathetic ganglia (Panula et al., 1987 and Lee et al., 1993). Later, they are identified to be highly condensed in the posterior pituitary, spinal cord, hypothalamus, and medulla in mouse, rat, the bovine, and human brain (Panula, Aarnisalo et al., 1996).

\section{CONCLUSION}

The current study represents the first evidence of the expression of FMRFamide peptides in the mammalian gastrointestinal tract. Also, we are suggesting that enteroendocrine cells are potential sources. Further investigations and characterizations are recommended.

\section{REFERENCES}

Gouardères, C.; Sutak, M.; Zajac J.M. and Jhamandas, K. (1993): "Antinociceptive effects of intrathecally administered F8Famide and FMRFamide in the rat." European journal of pharmacology 237(1): 73-81.

Haselton, A.T.; Yin, C.M. and Stoffolano, J.G. (2008): "FMRFamide-like immunoreactivity in the central nervous system and alimentary tract of the nonhematophagous blow fly, Phormia regina, and the hematophagous horse fly, Tabanus nigrovittatus." $\quad \underline{\mathbf{J}}$ Insect Sci 8: 1-17.

Lee, C.H.; Wasowicz, K.; Brown, R.; Majane, E.A.; Yang, H.Y.T. and Panula, P. (1993): "Distribution and Characterization of Neuropeptide FF-like Immunoreactivity in the Rat Nervous System with a Monoclonal Antibody."

European Journal of Neuroscience 5(10): 13391348.

Majane, E.A. and Yang, H.Y. (1990): "FMRF-NH2-like peptide is deficient in the pituitary gland of the Brattleboro rat." Peptides 11(2): 345-349.

Majane, E.A.; Zhu, J.; Aarnisalo, A.A.; Panula, $P$. and Yang, $H$. (1993): "Origin of neurohypophyseal neuropeptide-FF (FLFQPQRF-NH2)." Endocrinology 133(4): 15781584

Malin, D.H.; Lake, J.R.; Hammond, M.V.; Fowler, D.E.; Leyva, 
J.E.; Rogillio, R.B.; Sloan, J.B.; Dougherty, T.M. and Ludgate, K. (1990): FMRF$\mathrm{NH} 2$ like mammalian octapeptide in opiate dependence and withdrawal. Problems of Drug Dependence 1990 Proceeding of the 52nd Annual Scientific Meeting.

Oetken, M.; Bachmann, J.; SchulteOehlmann, $U$. and Oehlmann, J. (2004): "Evidence for endocrine disruption in invertebrates." Int Rev Cytol 236: 1-44.

Orchard, I.; Donly, B.C.; Fuse, M.; Lange, A.B.; Tobe, S.S. and Bendena, W.G. (1997): "FMRFamide-related Peptides in Insects, with Emphasis on the Myosuppressins." Annals of the New York Academy of Sciences 814(1): 307-309.

Panula, P.; Aarnisalo, A.A. and Wasowicz, K. (1996): "Neuropeptide FF, a mammalian neuropeptide with multiple functions." Progress in Neurobiology 48(4-5): 461-487.

Panula, P.; Kivipelto, L.; Nieminen, O.; Majane, E.A. and Yang, H.Y. (1987): "Neuroanatomy of morphine-modulating peptides." Med Biol 65(2-3): 127-135.

Peymen, K.; Watteyne, J.; Frooninckx, L.; Schoofs, $L$. and Beets, I. (2014): "The FMRFamide-Like Peptide Family in Nematodes." Frontiers in Endocrinology 5(90).
Price, D. and Greenberg, M. (1977):

"Structure of a molluscan cardioexcitatory

neuropeptide." 197(4304): 670-671.

$\underline{\text { Science }}$

Tang, J.; Yang, H. and Costa, E. (1984): "Inhibition of spontaneous and opiatemodified nociception by an endogenous neuropeptide with Phe-Met-Arg-Phe-NH2like immunoreactivity." Proceedings of the National Academy of Sciences 81(15): 5002-5005.

Vilim, F.S.; Aarnisalo, A.A.; Nieminen, M.L.; Lintunen, M.; Karlstedt, K.; Kontinen, V.K.; Kalso, E.; States, B.; Panula, $P$. and Ziff, $E$. (1999): "Gene for Pain Modulatory Neuropeptide NPFF: Induction in Spinal Cord by Noxious Stimuli." Molecular Pharmacology 55(5): 804-811.

Yang, $H$. and Martin, R. (1995): Isolation and characterization of a neuropeptide FF-like peptide from brain and spinal cord of rat. Soc Neurosci Abstr.

Yang, H.Y.; Fratta, W.; Majane, E.A. and Costa, E. (1985): "Isolation, sequencing, synthesis, and pharmacological

characterization of two brain neuropeptides that modulate the action of morphine." Proceedings of the National Academy of Sciences of the United States of America 82(22): 7757-7761. 


\section{دراسه نسيجوكيميائيه مناعية مبئية كثفت عن وجود البيتيا FMRFamide في الامعاء وفي العقد الجذرية الظهرية في الفئران}

ندى عبل اللاه عبل السميع عبل/للاه ، مليحه /حمد هاثم ، محد نبيل كامل مصطفى

E-mail: vet_nada@yahoo.com Assiut University web-site: www.aun.edu.eg

FMRFamide related-peptides

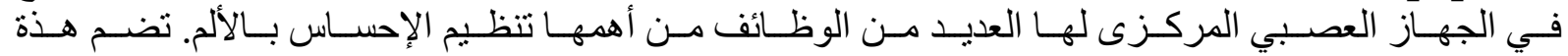

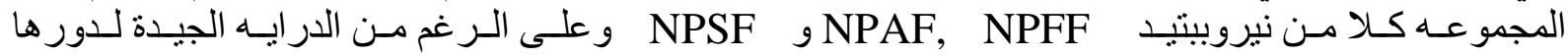

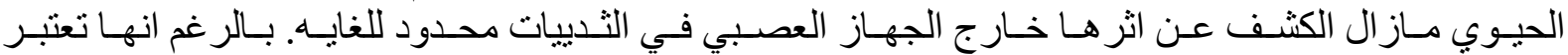

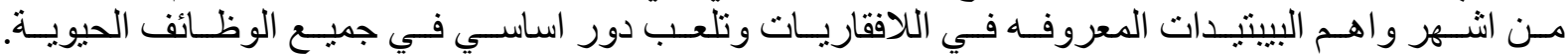

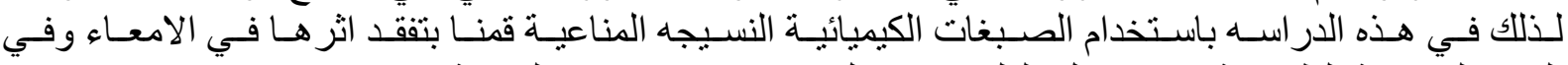



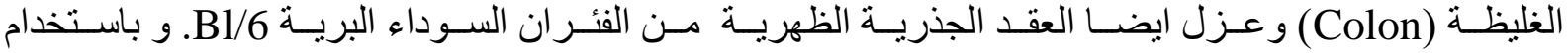

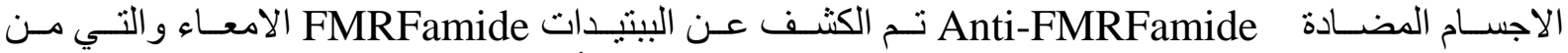

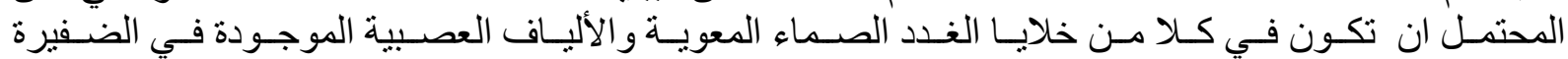

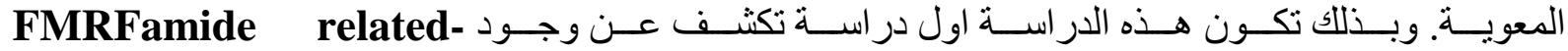
peptides 